\title{
Temporal and habitat distribution of macrophytes in lowland eutrophic reservoir Gruža in Serbia
}

\section{MARINA TOPUZOVIĆ \\ DRAGANA PAVLOVIĆ ALEKSANDAR OSTOJIĆ}

Faculty of Science, University of Kragujevac, Departman of Biology and Ecology,

Radoja Domanovica No.12, 34000 Kragujevac, Republic of Serbia

Correspondence: Marina Topuzović,

e-mail:marina@kg.ac.rs

Key words: macrophytes; horizontal extension; shoreline characteristics; distribution coefficient

Received October 10, 2014.

Revised March 23, 2016.

Accepted March 24, 2016.

\begin{abstract}
Background and Purpose: The research in this paper are based on the study of the distribution in time and space of macrophytes along the different parts of shoreline of Gruža Reservoir and emphasize the importance of establishing relations between distribution, diversity and mass of macrophytes and the ecological conditions of the environment. Development diversity of macrophytes needs to be constantly monitored and their regulation is necessary for Reservoir conservation, especially because the Reservoir is used as a water supply for a nearby city.
\end{abstract}

Materials and Methods: During the period 2004-2005 aquatic macrophytes were investigated (by the method of transects) bimonthly from May to October and results was compared with the results obtained during the research in 1986. Relative abundance was evaluated using a five degree scale. These data form the basis for the mathematical model with the following data: Relative Plant Mass for each species, cumulative Relative Plant Mass for growth forms and Mean Mass Indexes.

Results: Quantitative analysis of macrophytes indicates that the morphometrical characteristics of shoreline, water depth, vegetation characteristics and nutrient pollutants play an important role in the appearance, diversity and abundance of macrophytes.

Conclusions: The distribution of most aquatic macrophytes in Gruža Reservoir is heterogenous with mean mass indexes MMT (for all macrophytes in total stretches) and $M M O$ (for stretches with their occurrence) values of different size and with low value of distribution ratio. Our results have confirmed previously set hypothesis that poor physical conditions, rather than water quality, might be responsible for restricting diversity of macrophytes.

\section{INTRODUCTION}

acrophytes have significant role in productive and trophic rela1 tions, nutrient cycling, sedimentation processes, biofiltration as well as in maintaining stability of the dynamic equilibrium, wherefore they present one of the most important elements of aquatic ecosystems (1). Aquatic macrophytes are also indicators of water quality.

The presence of macrophytes is influenced by many factors: water quality, water depth, substrate characteristics, indentation and slope of the shoreline, pollution by nutrients etc. Even more than these characteristics, morphometrical characteristics of the Reservoir proved to be more reliable predictors for both species diversity and community structure than chemical ones $(2,3,4)$.

The overall aim of our study has been to detect habitat and temporal patterns in macrophytic vegetation, covering the relations between eco- 
logical conditions (such as morphometrical characteristics of the shoreline, water chemistry, water depth and nutrient pollutants) and aquatic vegetation in terms of species composition, distribution, diversity and mass and to compare our results with the results from 1986 (5).

We attempted to answer the following questions: What are the main determinants of the occurrence and the horizontal extension of macrophytes in four different shore habitats? What are the main patterns of temporal vegetation change in a shore habitat?

We have also focused on the following hypotheses:

- Water quality support development of macrophytic vegetation, but the different habitat characteristics along the shoreline cause different distribution of macrophytes,

- Favourable morphometrical conditions make quick colonization possible in still water.

\section{MATERIAL AND METHODS}

Gruža Reservoir, which is located in the central part of Serbia, at an elevation of $238 \mathrm{~m}$ above sea level, is $10 \mathrm{~km}$ long and 0.2-1.5 $\mathrm{km}$ wide, with surface area of $934 \mathrm{ha}$. Two thirds of the Reservoir are shallow (3-9 m), with maximum depth of $31 \mathrm{~m}$ and oscillations of water level of 3-5 m.

The water samples for the analysis of physical and chemical characteristics were taken together with those for quantitative analysis of macrophytes, bimonthly from May to October. during the period 2004-2005. At the approximate location where macrophyte cover was determined, water samples were collected directly above the vegetation beds by placing sample bottles approximately $50 \mathrm{~cm}$ below the water's surface for each four part of Reservoir (A, B, C and D in Fig 1). In every of these four parts of the 10 samples were taken from different points, at each point of sampling taken two samples were taken per site and merged together for analyses. Analyses of physical and chemical parameters were performed by standard methods and these values (which represents arithmetic mean value of all measurements) are given in Table 1.

During the period 2004-2005 aquatic macrophytes were investigated bimonthly from May to October. Aquatic macrophytes were surveyed in four parts of variable length (A, B, C and D in Fig 1) depending on morphometrical characteristics of the Reservoir, vegetation characteristics, water depth and human impact. In every homogeneous shoreline part colonized by macrophytes, we conducted investigations by the method of transects. Plants growing along the shore as well as in water, up to a depth of $5 \mathrm{~m}$, were collected (with grapple) and determinated according to Javorka and Csapody (6).

Relative abundance was evaluated using a five degree scale, according to the Kohler \& Schneider (7), as follows:
1 very rare, 2-infrequent, 3-common, 4-frequent, 5-abundant, predominant.

Data sets are used for description of quantitative relations of aquatic macrophyte vegetation. These data form the basis for the mathematical model with the following data: Relative Plant Mass for each species, cumulative Relative Plant Mass for growth forms and Mean Mass Indexes (8). Mean Mass Indexes are metric values for the average abundance of each species. MMT is a Mean Mass Index of one species in all surveyed units, while MMO is a Mean Mass Index of one species only in surveyed units where the species occurs. If the values of MMT exceed MMO values, the species have more heterogeneous distribution pattern. If MMO and MMT values are high, species occurs in large populations and vice verse (8). If values of MMT and $\mathrm{MMO}$ are leveled and low, species are present in all surveyed sections (homogeneous distribution pattern) with low plant masses, but if these values are leveled and high, species are present in large massive populations.

The distribution coefficient $\mathrm{d}$ is MMT/MMO ratio, which describes distribution continuity. If $\mathrm{d}=1$, the species is present in all survey units, if $d<0.5$, the species is present in a small number of survey units (a heterogeneous distribution pattern).

The degree of similarity between populations of macrophytes listed in our investigations (2004-2005) and in the 1986 (5) has been calculated by Sørenson similarity index $S$ (9).

\section{RESULTS}

The main indicators of eutrophic water status of Gruža Reservoir are physical, chemical (Tab 1) and biological

Table 1. Average values of some physical and chemical parameters of the Gruža Reservoir during the investigation period from May to October 2004 and 2005, both

\begin{tabular}{|c|c|}
\hline \multicolumn{2}{|l|}{ Water characteristics } \\
\hline Temperature $\left({ }^{\circ} \mathrm{C}\right)$ & 14.2 \\
\hline Disolved oxygen $\left(\mathrm{mg} \mathrm{l}^{-1}\right)$ & 4.98 \\
\hline Conductivity $\left(\mu S \mathrm{~cm}^{-1}\right)$ & 362 \\
\hline $\mathrm{pH}$ & 7.80 \\
\hline $\mathrm{KMnO}_{4}$ consump. $\left(\mathrm{mg} \mathrm{l}^{-1}\right)$ & 23.50 \\
\hline Total P $\left(\mu g ~^{-1}\right)$ & 0.06 \\
\hline Nitrites $\left(\mu \mathrm{g}^{-1}\right)$ & 0.01 \\
\hline $\mathrm{NH}_{4}^{+}\left(\mu \mathrm{g} \mathrm{l}^{-1}\right)$ & 0.22 \\
\hline $\mathrm{Ca}^{2+}\left(\mathrm{mg} \mathrm{l}^{-1}\right)$ & 51.5 \\
\hline $\mathrm{Mg}^{2+}\left(\mathrm{mg} \mathrm{l}^{-1}\right)$ & 27.1 \\
\hline Saturation \% & 44.3 \\
\hline Secchi depth (m) & 1.1 \\
\hline
\end{tabular}


Table 2. Relative Plant Mass RPM of the macrophytes in the parts of the Gruža Reservoir and for its whole in first investigation period (1986) (5) and in second investigation period (2004-2005) Abbreviation for years: for 2004-2005 - 05, for 1986-86-86

\begin{tabular}{|c|c|c|c|c|c|c|c|}
\hline \multirow[t]{3}{*}{ Plant species } & \multirow[t]{3}{*}{ Abbreviation } & \multirow[t]{3}{*}{ year } & \multicolumn{5}{|c|}{ RPM in \% } \\
\hline & & & \multicolumn{5}{|c|}{ Parts of Reservoir } \\
\hline & & & A & B & C & D & TOTAL \\
\hline \multicolumn{8}{|l|}{ Submerged } \\
\hline Ceratophyllum demersum $\mathrm{L}$. & Cer dem & 05 & 33.33 & 12 & 5.17 & 1.92 & 6.38 \\
\hline Ceratophyllum submersum $\mathrm{L}$. & Cer sub & 05 & 16.67 & 8 & 1.72 & 1.92 & 3.54 \\
\hline Myriophyllum spicatum $\mathrm{L}$ & Myr spi & 05 & 16.67 & 8 & 6.92 & 5.76 & 7.09 \\
\hline Myriophyllum verticillatum $\mathrm{L}$. & Myr ver & 05 & 16.67 & 4 & 3.45 & 3.85 & 4,25 \\
\hline Najas marina $\mathrm{L}$. & Naj mar & 05 & 16.67 & 4 & - & - & 1.42 \\
\hline \multirow[t]{2}{*}{ Potamogeton crispus $\mathrm{L}$. } & Pot cri & 05 & - & 4 & 5.18 & 3.85 & 4.26 \\
\hline & Pot cri & 86 & - & - & 10 & 15.4 & 11.77 \\
\hline \multirow[t]{2}{*}{ Potamogeton pusillus $\mathrm{L}$} & Pot pus & 05 & - & - & 3.45 & 1.92 & 2.13 \\
\hline & Pot pus & 86 & - & - & 5 & - & 2.94 \\
\hline Veronica anagallis-aquatica $\mathrm{L}$. & Ver ana & 05 & - & 4 & 3.45 & 1.92 & 2.84 \\
\hline \multirow{4}{*}{ Veronica beccabunga L. } & Ver bec & 05 & - & - & 1.72 & 1.92 & 1.42 \\
\hline & Ver bec & 86 & - & - & 5 & 7.69 & 5.88 \\
\hline & & 05 & Cumulativ & & & & 33.33 \\
\hline & & 86 & submerged & & & & 20.59 \\
\hline \multicolumn{8}{|l|}{\begin{tabular}{|l|} 
Floating \\
\end{tabular}} \\
\hline \multirow[t]{2}{*}{ Lemna gibba $\mathrm{L}$} & Lem gib & 05 & - & - & 3.45 & 1.91 & 2.13 \\
\hline & Lem gib & 86 & - & - & 10 & 7.69 & 8.82 \\
\hline \multirow[t]{2}{*}{ Lemna minor $\mathrm{L}$. } & Lem min & 05 & - & -- & 3.45 & 1.91 & 2.13 \\
\hline & Lem min & 86 & - & - & 10 & 7.69 & 8.82 \\
\hline Polygonum amphibium $\mathrm{L}$ & Pol amp & 05 & - & 12 & 6.90 & 7.69 & 7.80 \\
\hline \multirow[t]{4}{*}{ Potamogeton fluitans $\mathrm{L}$} & Pot flu & 05 & - & - & 3.45 & 3.85 & 2.84 \\
\hline & Pot flu & 86 & - & - & 10 & 15.4 & 11.7 \\
\hline & & 05 & Cumulativ & & & & 14.9 \\
\hline & & 86 & floating sp & & & & 29.41 \\
\hline \multicolumn{8}{|l|}{ Emerged } \\
\hline \multirow{2}{*}{ Alisma plantago- aquatica $\mathrm{L}$} & Ali pla & 05 & - & 4 & 3.45 & 3.85 & 3.54 \\
\hline & Ali pla & 86 & - & - & 5 & 7.65 & 5.88 \\
\hline Butomus umbellatus $\mathrm{L}$. & But umb & 05 & - & - & 3.45 & 3.85 & 3.54 \\
\hline Glyceria fluitans (L.) R.Br. & Gly flu & 05 & - & - & 1.72 & 3.85 & 2.13 \\
\hline \multirow[t]{2}{*}{ Eleocharis palustris (L.) R.Br. } & Ele pal & 05 & - & 8 & 5.17 & 7.69 & 6.38 \\
\hline & Ele pal & 86 & - & - & 10 & 23.1 & 14.71 \\
\hline Iris pseudacorus $\mathrm{L}$. & Iri pse & 05 & - & 4 & 5.17 & 3.85 & 4.26 \\
\hline Lycopus exaltatus L. & Lyc exa & 05 & - & 4 & 5.17 & 5.76 & 4.96 \\
\hline \multirow[t]{2}{*}{ Lycopus europaeus L. } & Lyc eur & 05 & - & 4 & 5.17 & 5.76 & 4.96 \\
\hline & Lyc eur & 86 & - & 100 & 5 & - & 5.88 \\
\hline Lythrum salicaria $\mathrm{L}$. & Lyt sal & 05 & - & 4 & 1.72 & 1.92 & 2.13 \\
\hline & Lyt sal & 86 & - & - & 5 & - & 2.94 \\
\hline Mentha aquatica L. & Men aqu & 05 & - & 8 & 6.9 & 7.69 & 7.09 \\
\hline Mentha spicata ssp. tomentosa Urv. & Men spi & 05 & - & 4 & 1.72 & 3.85 & 2.84 \\
\hline Oenanthe aquatica (L.) Poir & Oen aqu & 05 & - & 4 & 1.72 & 1.92 & 2.13 \\
\hline Phragmites australis Trin & Phr aus & 05 & - & - & 3.45 & 1.92 & 2.13 \\
\hline Scirpus silvaticus $\mathrm{L}$. & Sci sil & 05 & - & - & 1.72 & 1.92 & 1.42 \\
\hline & Sci sil & 86 & - & - & 5 & - & 2.94 \\
\hline Schoenoplectus palustris L. & Sch pal & 86 & - & - & 10 & 15.4 & 11.77 \\
\hline Typha angustifolia $\mathrm{L}$. & Typ ang & 05 & - & - & 3.45 & 3.85 & 2.84 \\
\hline & Typ ang & 86 & - & - & 5 & - & 2.94 \\
\hline Typha latifolia $\mathrm{L}$. & Typ lat & 05 & - & - & 1.72 & 1.92 & 1.42 \\
\hline & Typ lat & 86 & - & - & 5 & - & 2.94 \\
\hline & & 05 & Cumulativ & & & & 33.33 \\
\hline & & 86 & emerged $s_{\mathrm{F}}$ & & & & 20.59 \\
\hline Sørenson index for parts & & & & 0.111 & 0.634 & 0.457 & \\
\hline Sørenson index for whole reservoir & & & & & 0.619 & & \\
\hline
\end{tabular}


parameters: chlorophil a, zooplankton and microbiological (10) water characteristics.

The presence and composition of macrophytic vegetation is determined by eutrophyc status of the Reservoir, wherefore the eutrophic species are dominant - Potamogeton crispus, Phragmites australis, Ceratophyllum demersum, C. submersum. These species indicate highly eutrophic waters (7).

Comparison of our research data of aquatic macrophytes with the data of investigations from 1986 (5) were established into four parts of the Reservoir and presented in Table 2. The data reveals that in the dam part A (Fig 1 , Tab 2) submerged species are represented by few species with low RPM. Floating and emerged species are not present. The results of investigations from 1986 did not record macrophytes in this part of the Reservoir (5).

There are more recorded species in Part B (Fig 1, Tab 2), but the coverage is still small. In 1986 only very poor

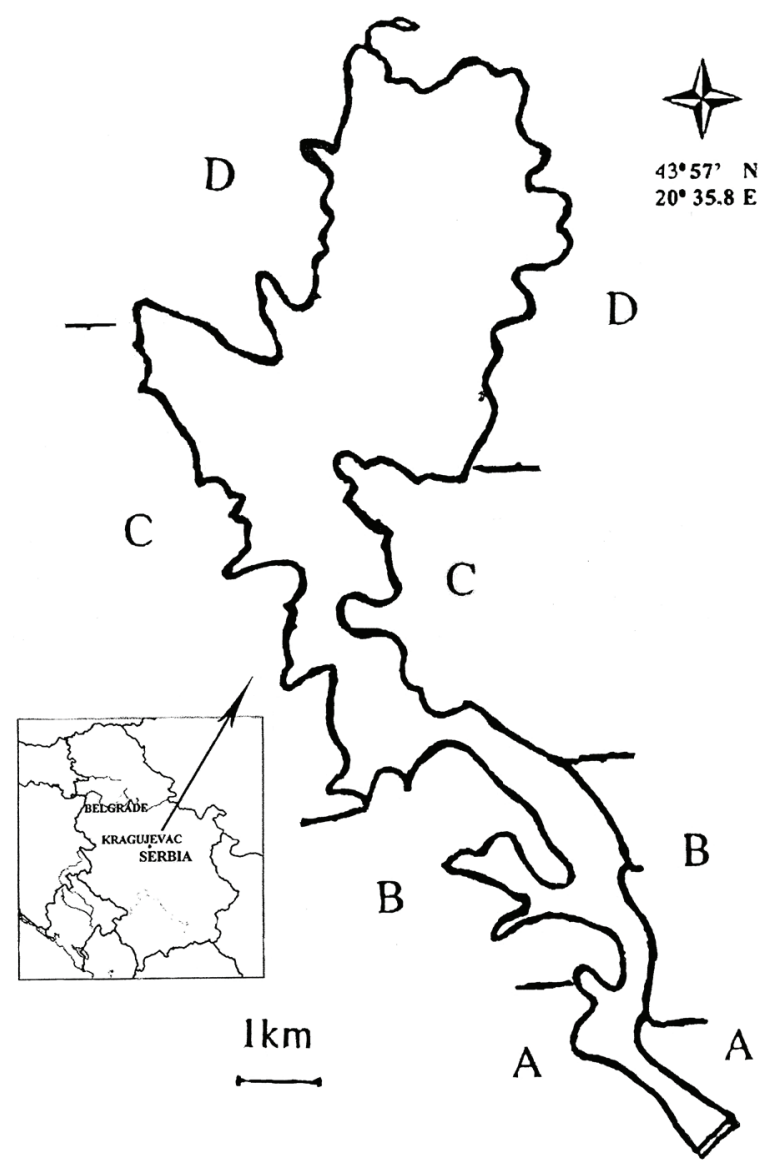

Figure 1. Map of Gruza Resevoir

Parts of the Reservoir: A- (next to both sides of the dam) banks are steep, unindented, naked, great depths just off shore, max depth is $31 \mathrm{~m}$; $B$-shoreline is little more indented and less steep, and the water is less deep, max depth is $21 \mathrm{~m}$; C-shoreline is shallow, muddy, indented, surrounded by arable fields, with max depth of $9 \mathrm{~m}$; $D$ - shoreline is shallow, muddy, surrounded by arable fields, with a very gently-sloping littoral, max depth is $3 \mathrm{~m}$. macrophytic vegetation was present (5). Low value of $S \varnothing$ renson similarity index indicates that there is a difference in the state of macrophytes between 2004-2005 and 1986. Parts $\mathrm{C}$ and D (Fig 1, Tab 2) are the richest in species and coverage both in the first (1986) and in the second (2004$05)$ investigations period. The values of Sørenson similarity index indicates that there is small difference in the state of macrophytes between 2004-2005 and 1986.

Zonation by depth is expressed in these parts. The zone of emerged plants is the richest in species and percentage of RPM, both in these two parts as well as in the Reservoir in its whole (Tab 2), followed by zones of submerged and floating vegetation.

The analysis of Fig 2 points out that MMT (gray bars) and MMO (black bars) values obtained in our researches during the period 2004-2005 are low for most plant species indicating that the species occur in small populations. These values are low and leveled for species which are present in all surveyed parts (homogenous distribution pattern) with low plant masses - Ceratophylum demersum, C. submersum, Myriophyllum spicatum and M. verticillatum. Distribution ratio d (Fig 4) for these species has a value 1 . For all the other species values of MMT exceed MMO values (Fig 2). These species have heterogeneous distribution pattern, as shown in Fig 3 -values d (gray bars) are $<1$. Even more pronounced heterogeneous distribution is present within species Najas marina, Typha latifolia, T. angustifolia, Scirpus sylvaticus, Veronica beccabunga, Glyceria fluitans Lemna gibba, Potamogeton pussilus and P. fluitans ( $\mathrm{d}=0,5$ in Fig 4, white bars) since they occur in two out of four surveyed parts.

According to our researches the distribution of most aquatic macrophytes in Gruža Reservoir as a whole, is heterogenous with MMT and MMO values of different size (Fig 2) and with low value of distribution ratio (Fig 4 , gray bars).

In Fig.3 and Fig 4, made upon the data from 1986 (5), it is evident that values of MMT and MMO are not equal for the recorded species and that heterogeneity was more expressed - not a single species recorded at the time had the value d exceeding 0.5 (black bars in Fig 4).

\section{DISSCUSION}

Our researches of macrophytes in Gruža Reservoir have been performed systematically as well as compared to the results of previous researches. According to the obtained results the habitat and temporal patterns in macrophytic vegetation have been determined, covering the relations between morphometrical characteristics of the shoreline, water depth and nutrient pollutants, as well as aquatic vegetation (species composition, distribution, diversity and mass).

Our results have confirmed previously set hypothesis that physical conditions (such as a steep rocky banks where 


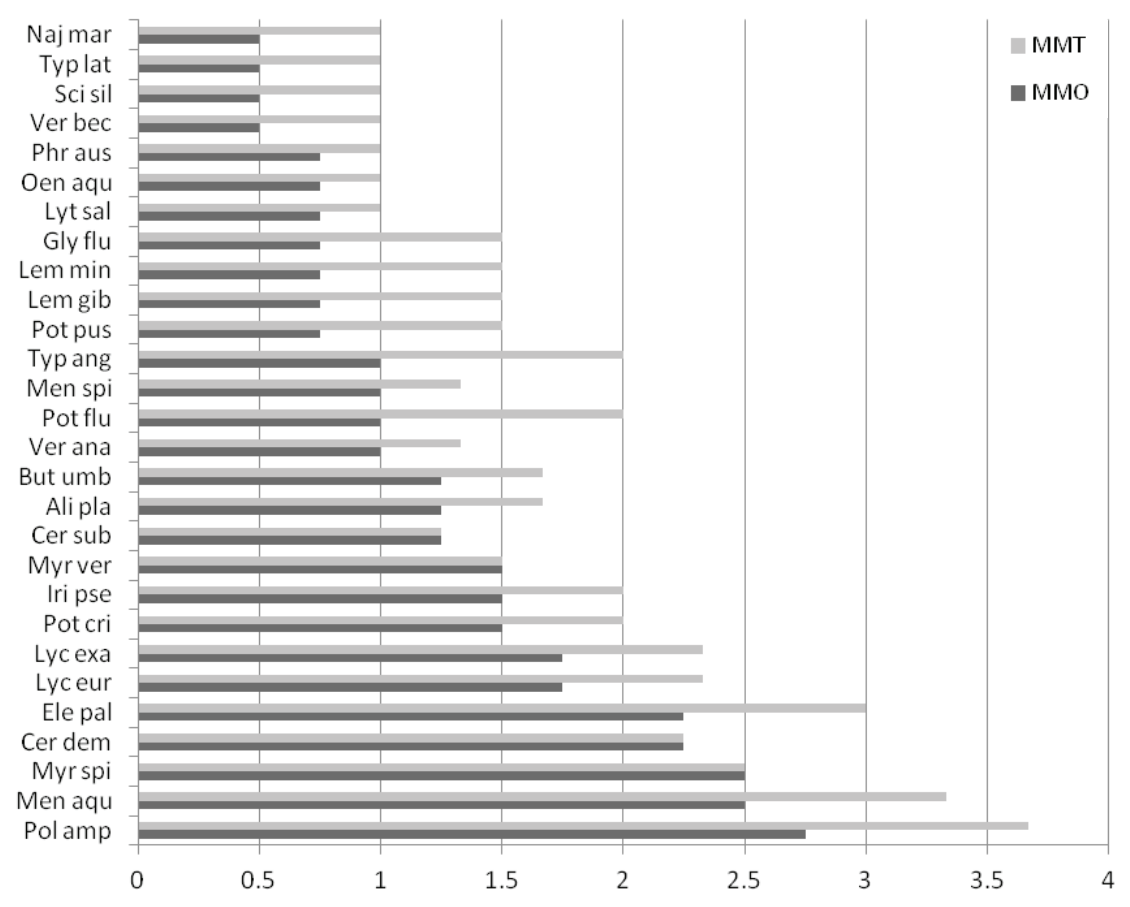

Figure 2. Mean Mass Indexes - MMT, $M M O$ calculated for all macrophytes in stretches with their occurrence (MMT, gray bars) and total stretches (MMO, black bars) in Gruza Reservoir for the investigation period 2004-2005

great depths are just off shore), rather than water quality, might be responsible for restricting diversity of macrophytes. In Gruža_Reservoir water quality (eutrophic conditions) support development of macrophytic vegetation $(1,11)$, but the different habitat characteristics along the shoreline cause different distribution of macrophytes. Main determinants of the occurrence and the horizontal extension of macrophytes in four different shore habitats are shown to be morphometrical characteristics of shoreline (indentation of the shoreline, its slope, muddy banks), water depth and pollution by nutrients $(1,3,12)$. A pronounced poverty in species with small coverage has been recorded in the part of the lake around the dam, which has the form of a gorge with steep rocky banks that are virtually naked and where great depths are just off shore. Due to these physical conditions biodiversity is restricted. In parts of the lake with the shallowest water and greatest indentation of the shoreline, where nutrients are constantly leached into it, the greatest diversity and RPM of species has been recorded.

The main pattern of temporal vegetation change in the shore habitat are favourable morphometrical conditions, which make possible quick colonization - in the first year after the Gruža Reservoir formation, the shallow and muddy littoral was overgrown with macrophytes, most extensively in the inlets (5), confirming that the degree of indentation of the shoreline is a very significant factor in the formation of macrophytic vegetation (3). The data for Kis-Balaton reservoir (13) and for Yacireta reservoir (4), regarding to quickness of the development of macrophytes, correspond to our data.
High degree of similarity between the two time of analysis has been confirmed with high value of the Sørenson similarity index for Gruža reservoir in its whole (Table 2). Comparison with the results from investigated period 2000-2003 (14) shows that there are no differences in species diversity. This shows that the first changes in flora occurred very quickly, while in recent years the changes in vegetation structure seem to be much slower.

For Gruža Reservoir as a whole, the presence of macrophytes is not excessive, since frequent fluctuations of water level limit their development $(15,16)$, especially the development of emerged plants, which are the richest in

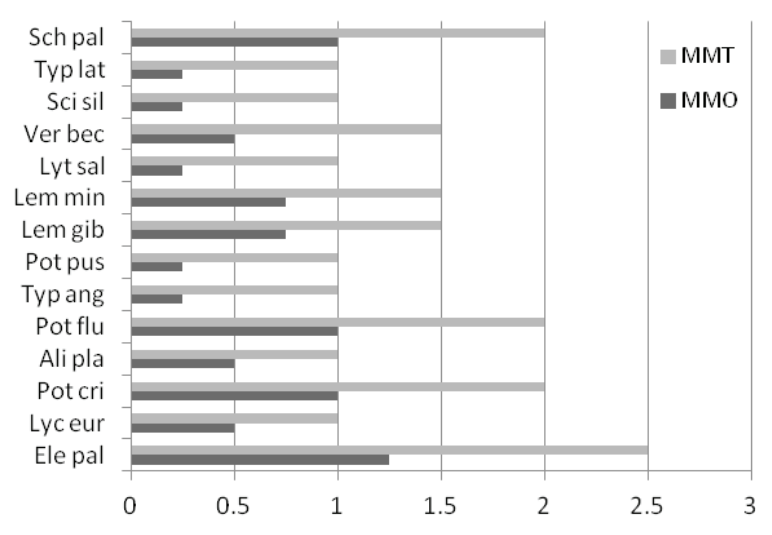

Figure 3. Mean Mass Indiexes - MMT, MMO calculated for all macrophytes in stretches with their occurrence (MMT, gray bars) and total stretches (MMO, black bars) in Gruza Reservoir based on the results from 1986. 


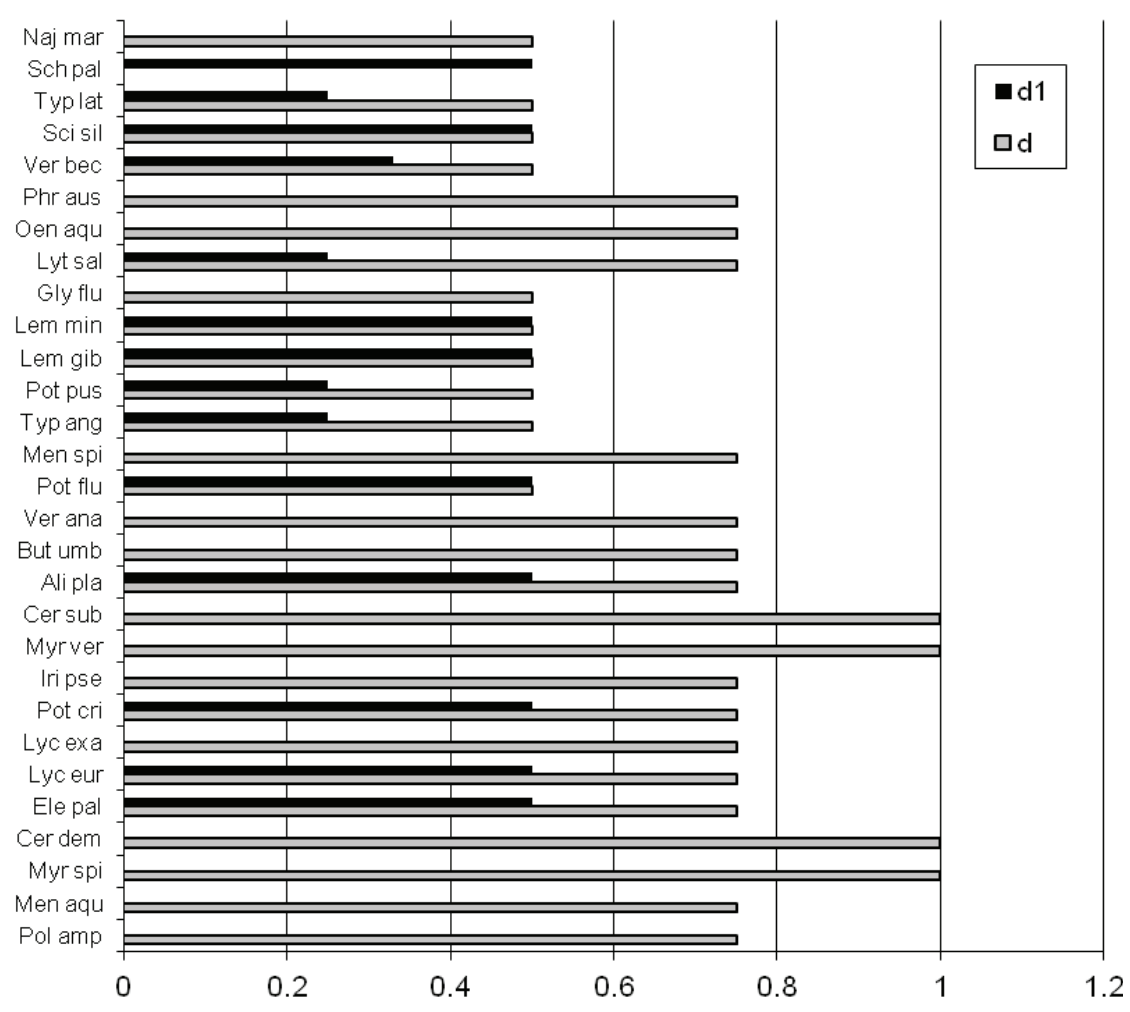

Figure 4. Distribution ratio d of aquatic macrophytes in Gruza Reservoir for the investigation period 2004-2005 (gray bars) compared with results from 1986 (black bars)

diversity and whose death is followed by accumulation of lignin and cellulose. These difficultly soluble substances lead to creation of anaerobic conditions in the sludge, contributing to the process of eutrophication.

In this stage, macrophytes represent a desirable component, both as competitors with algae for nutrients and regulators of phytoplankton development, as well as biological filters (through the accumulation of nutrients and pollutants and later harvest $(3,17)$, since great influx of allochtonous nutrients enters the Reservoir from arable fields, which extends along two thirds of the circumference of the reservoir.

Distribution in time and space, as well as development diversity, composition and abundance of macrophytes in Gruža Reservoir needs to be constantly monitored and their regulation is necessary for Reservoir conservation, especially because the Reservoir is used as a water supply for a nearby city.

\section{ACKNOWLEDGMENTS}

This work was supported by the Ministry of Science and Technological Development, Republic of Serbia.

\section{REFFERENCES}

1. WETZEL RG 1983 Lymnology. W.B. Saunders Co., Philadelphia, PA: 767p

2. MÄKELÄ S, HUITU E, ARVOLA L 2004 Spatial patterns in aquatic vegetation composition and environmental covariates along chains of lakes in the Kokemäenjoki watershed (S. Finland). Aquatic Botany 80 (4): 253-269

http://dx.doi.org/10.1016/j.aquabot.2004.08.006

3. HEEGAARD E, BIRKS HH, GIBSON CE, SMITH S, WOLFEMURPHY S 2001 Species- environmental relationships of aquatic macrophytes in Northern Ireland. Aquatic Botany 70: 175-223

4. NEIFF J J, POI DE NEIFF A S G, PATINO C A E, BASTERRA DE CHIOZZI I 2000 Prediction of colonization by macrophytes in the Yaciretá Reservoir of the Paraná River (Argentina and Paraguay). Rev Bras Biol 60 (4): 1-19

5. VELJOVIĆ V, MARKOVIĆ A, VUKOMANOVIĆ V 1986 Dijagnosticki znacaj pojave makrofitske.flore i vegetacije u novoformiranim akumulacionim jezerima. Konferencija „Zastita voda 86“, Zbornik radova 82-86

6. JAVORKA S, CSAPODY V 1979 Ikönographie der Flora des Sudostlichen Mitteleuropa. Gustav Fisher Verlag, Stuttgart. 704pp

7. KOHLER A, SCHNEIDER S 2003 Macrophytes as bioindicators. In: G.A. Janauer G A, Hale P, Sweeting R, (ed) Macrophyte inventory of the river Danube: a pilot study, Arch Hydrobiol Suppl 147 (1-2): 17-31

8. JANAUER, G A 2003 Methods. In: Janauer, G A, Hale P, Sweeting R (eds) Macrophyte inventory of the river Danube: A pilot study Large Rivers. Arch Hydrobiol Suppl 147 (1-2): 9-16

9. SCHWERDTFEGER F 1975 Ökologie der Tire. Band 3: Synökologie. Paul Parey Verlag, Hamburg-Berlin 678p

10. OSTOJIĆ A, CURCIĆ S, COMIĆ LJ, TOPUZOVIĆ M 2005 Estimate of the Eutrophication Process in the Gruza Reservoir (Serbia and Montenegro). Acta hydrochim. hydrobiol. 33 (6): 605613 http://dx.doi.org/10.1002/aheh.200500601

11. MOSS B 1990 Engeneering and biological approaches to the restoration from eutrophication of shallow lakes in which aquatic plant communities are important components. Hydrobiologia 200/201: 367-377 http://dx.doi.org/10.1007/BF02530354 
12. IRFANULLAH H, MOSS B 2004 Factors influencing the return of submerged plants to a clear-water, shallow temperate lake. Aquatic Botany 80: 177-191

13. POMOGY P 1989 Macrophyte communities of the Kis-Balaton reservoir. Symp.Biol. Hung. 38, Academia Kiado, Budapest. In: Salaki J, Herodek S, (ed) Conservation and Management of Lakes 1-6

14. TOPUZOVIĆ M, PAVLOVIĆ D 2004 Physical organization of two reservoirs in Serbia as a crucial factor in development of their hydrophilic flora: a comparative study. Hydrobiologia 525: 239-243 http://dx.doi.org/10.1023/B:HYDR.0000038863.71196.42
15. HELLSTEN S, RIIHIMÄKI J 1996 Effects of lake water level regulation on the dynamics of littoral vegetation in Northern Finland. Hydrobiologia 340: 85-92

http://dx.doi.org/10.1007/BF00012738

16. TARVER D P 1980 Water fluctuation and the aquatic flora of Lake Miccosukee. Journal of Aquatic Plant Management 18: 19-23

17. ENGEL $S 1990$ Ecological impacts of harvesting macrophytes in Halverson Lake, Wisconsin. Journal of Aquatic Plant Management 28: 41-45 